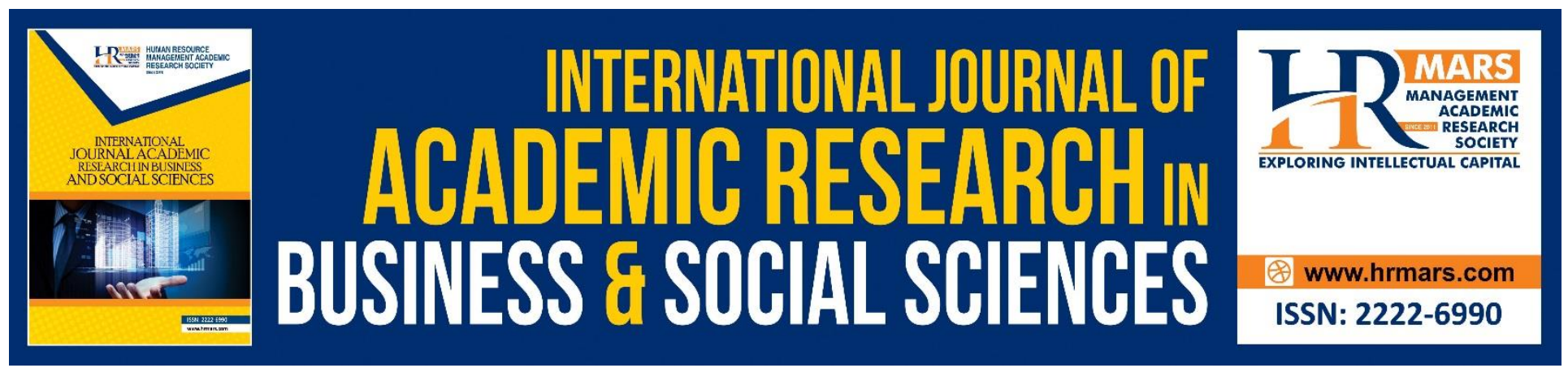

\title{
Halal Food Processing and the Relationship with Management Accounting Techniques: A Study from the Malaysian Practices
}

Abdul Aziz Abdullah \& Mohd Rizuan Abdul Kadir

To Link this Article: http://dx.doi.org/10.6007/IJARBSS/v8-i11/5172

DOI: 10.6007/IJARBSS/v8-i11/5172

Received: 17 Oct 2018, Revised: 26 Nov 2018, Accepted: 02 Dec 2018

Published Online: 05 Dec 2018

In-Text Citation: (Abdullah \& Kadir, 2018)

To Cite this Article: Abdullah, A. A., \& Kadir, M. R. A. (2018). Halal Food Processing and the Relationship with Management Accounting Techniques: A Study from the Malaysian Practices. International Journal of Academic Research in Business and Social Sciences, 8(11), 1311-1323.

Copyright: (c) 2018 The Author(s)

Published by Human Resource Management Academic Research Society (www.hrmars.com)

This article is published under the Creative Commons Attribution (CC BY 4.0) license. Anyone may reproduce, distribute, translate and create derivative works of this article (for both commercial and non-commercial purposes), subject to full attribution to the original publication and authors. The full terms of this license may be seen at: http://creativecommons.org/licences/by/4.0/legalcode

Vol. 8, No. 11, 2018, Pg. 1311 - 1323

Full Terms \& Conditions of access and use can be found at http://hrmars.com/index.php/pages/detail/publication-ethics 


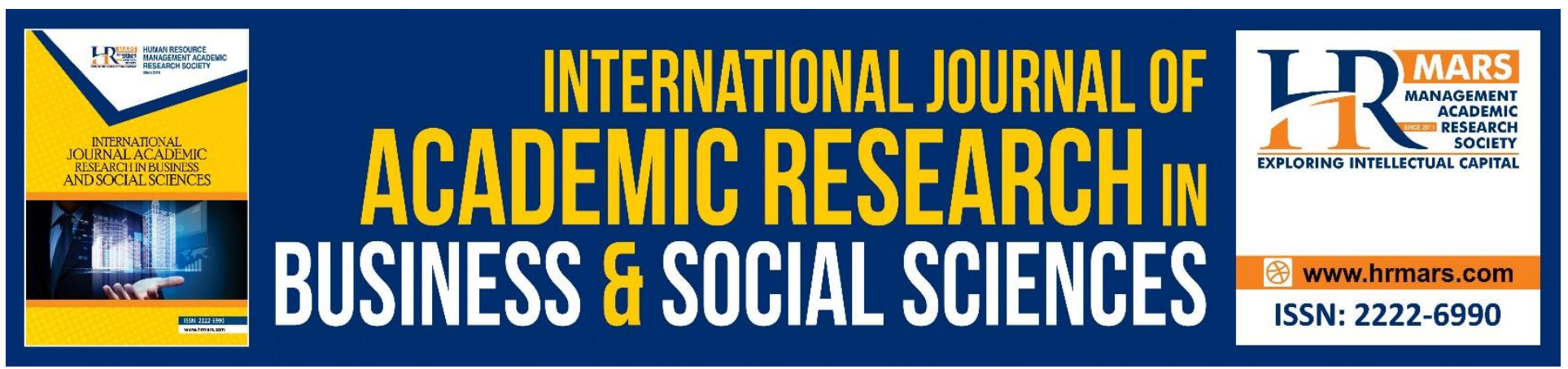

\title{
Halal Food Processing and the Relationship with Management Accounting Techniques: A Study from the Malaysian Practices
}

\author{
Abdul Aziz Abdullah \\ Faculty of Economy and Management Sciences, Universiti Sultan Zainal Abidin \\ Email: abdulazizum@gmail.com \\ Mohd Rizuan Abdul Kadir \\ College of Business Administration and Accounting, Universiti Tenaga Nasional \\ Bandar Muadzam Shah, 27600 Pahang, Malaysia. \\ Email:mrizuan@uniten.edu.my
}

\begin{abstract}
In Islam, there are two basic requirements on food for human consumption, which are halal and toyyib. Halal signifies the permitted food in Islam, whereas toyyib stresses about purity of food. In brief, halal food in Islam shall comprise only permitted ingredients (halal) and needs to be submitted through a good processing system. This to ensure that food is hygienic and safe for consumption. In order to secure a good processing, other Islamic values such as avoid wastage and effectively use of resources are incorporated as part of the halal food processing. In Malaysia, this process is governed by the MS 1500:2009. This process is expected to lead the food producers to a good food processing system. Therefore, this study is designed to investigate the practices of halal food processing and its relationship with management accounting technique. A questionnaire survey was used and distributed to the respondents involved in halal food industries. The results of the study confirmed that halal food processing is a good processing system. Moreover, this study revealed that there are elements of Management Accounting (MA) techniques being implemented in this processing. This study concluded that halal food is beyond the Muslim's food issues. It is a universal concept on food processing that shall be applied to all food producers.
\end{abstract}

Keywords: Halal Management, Halal Processing, Management Accounting

Concept of Halal Food in Islam

Islam has mentioned two basic principles of food to be consumed by human, which are Halalan and Toyyibban. This is stated in the Quran, as God says: "O people, eat permissible good things out of 
what lies in the earth, and do not follow the footsteps of Satan; indeed, he is an open enemy for you" (Quran 2:168). And, in other verse, God describe specific items to be prohibited, as He says, "He has only forbidden you only for the dead animal, and blood, and the flesh of swine, and that which is slaughtered as a sacrifice for others than God (or been slaughtered for idols, in which God's name has not been mentioned while slaughtering)" (Quran 2:172-173).

In Islam, another major source of principles are coming from sunnah (tradition) of Prophet Muhammad PBUH. There are specific prohibitions mentioned by Prophet Muhammad PBUH on food consumption, such as a hadith reported by Muslim, "Every intoxicant is khamr (liquor), and every khamr is haram.", and in another hadith, Prophet Muhammad PBUH said, "Every fanged beast is forbidden to eat".

The concept of food prohibition is expanded by the Jurists using 'illah (legal reason). For example from the pulpit of Prophet Muhammad PBU, Umar al-Khatab had declared, "Khamr is that which befogs the mind" (Al-Qaradawi, 2001), and jurists agreed that anything belongs to this group is also prohibited. The major reason for the prohibition on these foods is, it brings harm to human. Although some would argue that these foods also have benefits, but its harms outweigh the benefits, thus it is not good for human (Al-Qaradawi, 2001).

To be specific, halal is defined as permitted or acceptable by Shariah law (Saifuddeen, 2006). Basically in Islam, anything edible is allowed, unless mentioned specifically in shariah law, such as prohibition of pork and liquor. Whereas, toyyib is a universal notion which can be referred to the food which is nutritious, good quality, hygiene, authentic and safe (Saadan \& Zainal Abidin, 2014; Saifuddeen, 2006). Toyyib also is referred to the good method used for ensuring the quality and safety of food (Mohamad \& Backhouse, 2014).

In Islam, eating good food is highly encouraged. The food to be consumed must be halal and pure. This shall be taken from the aspects of quality, safety, hygiene and sanitation (Mohamad \& Backhouse, 2014). Yaakob et al. (2007) outlined that there are three important considerations in selecting of food and drinks in Islam, which are; (i) whether the consumption of the foodstuff is prohibited by God; (ii) whether the foodstuff is obtained through halal or haram means, and (iii) whether or not the material is harmful to health. (Cwiertka, K \& Walvaren, B, 2002) did not only focused on how the food were processed, but also the way of preparation, sales and consumption of food.

As it is concerned, toyyib concept fits with the United Kingdom (UK) Food Law and European Union (EU) General Food Law in terms of the health risk associated to consumptions, and it is also associated with the hazard analysis and critical control points (HACCP) requirements (Mohamad \& Backhouse, 2014). Therefore, the toyyib concept in halal processing, which incorporated other Islamic values in it such as avoiding wastage and effectively use of resources, might inherently embedded other good elements.

\section{Malaysian Halal Food Standard MS1500:2009}

In Malaysia, the halal food processing standard is governed by MS1500:2009. This standard is a set of guidelines, covered on halal and the element of food processes to ensure the quality and safety of good. This standard also covers the guidelines on Food Safety Principle (MS1514), Hazard Analysis Critical Control Point (HACCP-MS1480) as well as the guidelines for good hygienic practice (GNP) and 
INTERNATIONAL JOURNAL OF ACADEMIC RESEARCH IN BUSINESS AND SOCIAL SCIENCES

Vol. 8, No. 11, Nov, 2018, E-ISSN: 2222-6990 @ 2018 HRMARS

Sanitation Standard Operating Procedures (SOPs). The guidelines not only fulfil the halal requirement, but also maintain standards that meet global benchmark such as ISO 9000 and Codex Alimentarius and Hazard Analysis Critical Control Point (HACCP).

Overall, about $40 \%$ of the standard is about halal, while another $60 \%$ is concern about hygiene and safety, which is the element of toyyib concept. Therefore, Malaysian halal food is not about halal only, but also the hygienic and safe food. It follows the standard requirements for hygiene and sanitation, and must harmless to health (IslamOnline.net, 2006). Currently, Malaysia's halal certification is globally recognised (Bohari, Hin, \& Fuad, 2013). The Malaysia Standard MS1500:2009 prescribes practical guidelines for the food industry on the whole processes of preparing and handling of halal food, starting from the selection of raw materials until the distribution and marketing activities (Samori,Ishak, \& Kassan, 2014).

In brief, the meaning of halal and its dimension covered by MS1500:2009 can be tabulated as in Figure 1.

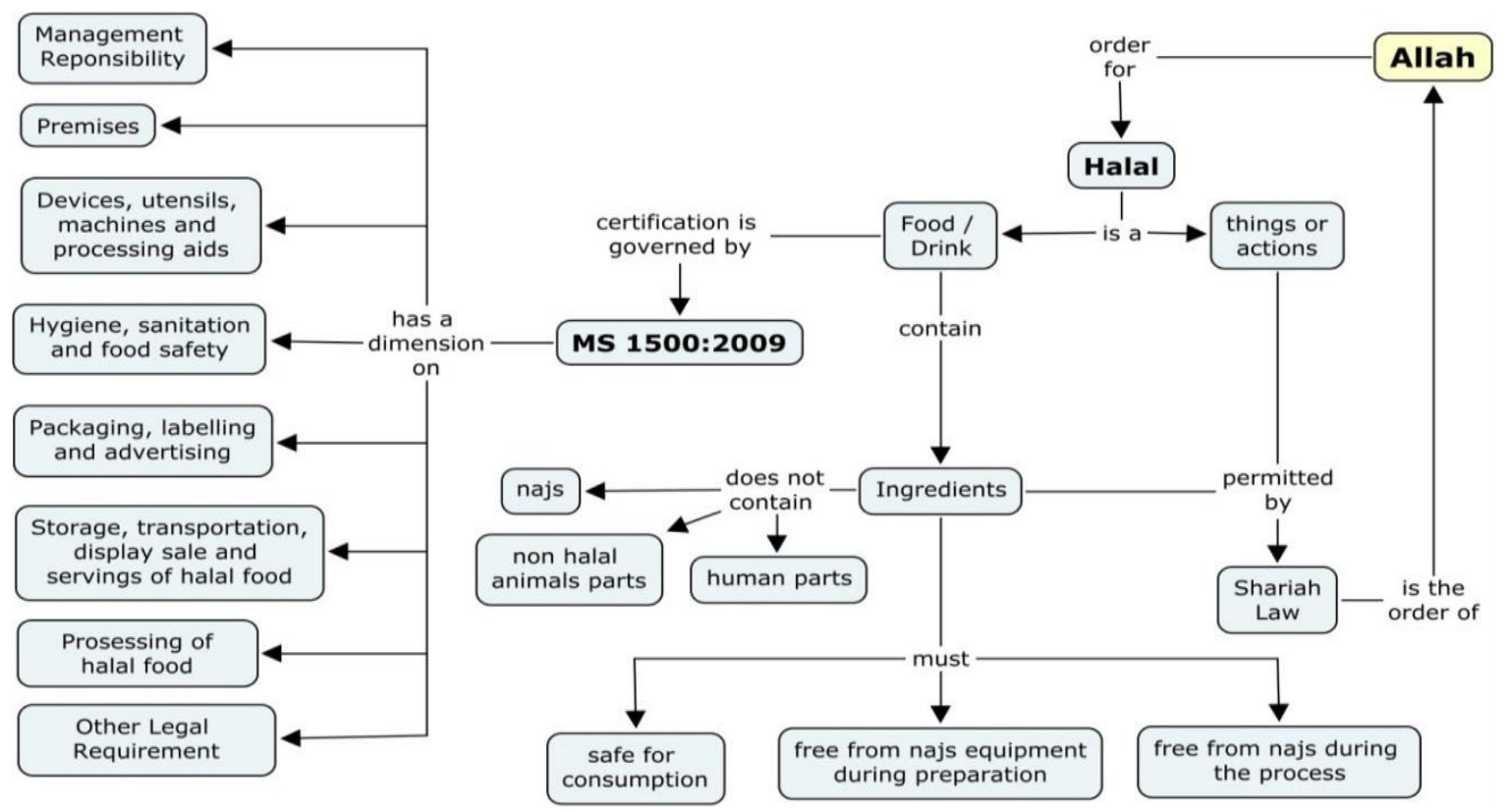

Source: Mohd Rizuan (2015)

Figure 1: The Meaning of Halal and Dimension Covered By MS1500:2009

In ensuring the good processes to guarantee the quality of food, the toyyib concept involved a lot of discretion on the best practices. The discretionary in halal food processing consequently relate to other good concepts in Islam such as waste management and use of resources effectively (Mohd Rizuan, Zaifudin, Salina, \& Noraina Mazuin, 2015). Halal food were certified as long as the food processed were examined in its preparation, processing, cleaning, handling, storing, transportations and management practices (Mohd Yusoff, 2004). Barely, little attention was given on the cost management in the standard. However, by upholding the Islamic concepts during the process, it shall lead to a good food processing system. Therefore, it is expected that the current halal food processing system is a comprehensive system. With that, it shall also expect that some of the Management Accounting (MA) techniques have been incorporated into it. Currently, there are a lot 
INTERNATIONAL JOURNAL OF ACADEMIC RESEARCH IN BUSINESS AND SOCIAL SCIENCES

Vol. 8, No. 11, Nov, 2018, E-ISSN: 2222-6990 @ 2018 HRMARS

of studying have been carried out on halal food processing (toyyib) and the use of MA techniques by business organisation, but none of the studies was tried to relate these concepts.

\section{Issues of Halal Processing and Management Accounting}

The global halal food industry increase tremendously. The global halal food market is worth US1.1tn in 2013 and is expected to hit US\$1.8tn in 2018 (Beer, 2014). With the large increment, the halal industry is no longer considered an industry merely to comply with religious requirements. Halal food industry has become an economic force in its own right (Mohamad \& Backhouse, 2014). Many countries are competing to take advantages on the huge halal market. Malaysia, Indonesia and Pakistan are among the Muslim countries aspired to become the halal hub. They are aggressively working towards becoming the key players in delivering halal products (Mohamad \& Backhouse, 2014).

The non-Muslim countries are also actively taking part in this market. China for example, a country with minority Muslims, managed to export $\$ 500$ billion of halal food (Dasgupta, 2011). Therefore, Malaysian halal food manufacturers should take positive actions in sustaining the halal food quality. This, in return, will help Malaysia become the halal hub and grab the global market opportunity (Habibah, Talib, Anuar, Ali, \& Jamaludin, 2008).

It should be noted that halal does not only related to permissible foods for Muslim but it also has other dimensions within Islam itself. Halal and toyyib themselves, portray the symbol of intolerance in hygienic, safety and quality of food (Noordin, Md Noor, Hashim, \& Samicho, 2009). Halal does not only require the food producers to use permitted materials, but also having good processes as outline in Islamic teaching. Halal processing highly requires cleanliness in the process and to use resources effectively. Thus, MS1500:2009 has specific requirement mentioned about minimising wastage and ensuring smooth process flow to avoid contamination. These practices indirectly relate to the MA. MA is part of accounting involves with the techniques of decision making, formulate planning and performance management systems (UNDSD, 2001). It is used to help the organisation operate in correct way (Anastas, 1997). Among the MA techniques that are proven helped companies to operate effectively are; Material Flow Cost Accounting (MFCA) (Chompu-inwai, Jaimjit, \& Premsuriyanunt, 2014; Kokubu \& Kitada, 2014), Kaizen Costing (KC) (Jayeola, Sokefun, \& Oginni, 2012; Monden \& Hamada, 1991; Poretsky, 2012), Variance Analysis (VA) and Benchmarking (BM) (Lankford, 1996).

Therefore, this study is designed to examine the halal food processing and its relationship with the used of MA techniques. The specific research questions to be answered in this study are:

1. Do halal food producers follow the MS1500:2009 requirement on hygiene and safety of food as outline?

2. What are the MA techniques inherently practiced by food producers in their halal food processing?

3. Is there any significant relationship between MS1500:2009 requirement on hygiene and safety of food processing and MA techniques? 
INTERNATIONAL JOURNAL OF ACADEMIC RESEARCH IN BUSINESS AND SOCIAL SCIENCES Vol. 8, No. 11, Nov, 2018, E-ISSN: 2222-6990 @ 2018 HRMARS

\section{Halal Food Processing and the Relationship with Management Accounting (MA) Techniques}

MA is used to help the organisation operate in correct way to be successful (Anastas, 1997). The used of MA shall contribute or generate idea for managers to make better decision that will benefit the company. Among the MA techniques that are proven and had helped companies to operate efficiency are MFCA, KC, VA and BM. The elements of these techniques are used in this study.

MFCA is an environmental management accounting (EMA) tool developed in Germany. It is focusing on tracing waste, emissions and non-product, and can help to improve economic and environmental performance of the organisation. MFCA tracks all input materials that flow through the production process, and measure the output of finished products and waste (Kokubu, Kos, \& Campos, 2009). Halal processing has some elements of MFCA when it requires traceability of material consumed as critical point to be look out. Traceability is very important for halal certification to ensure every resource used in the processing is halal and from the good sources. The knowledge about the composition in the process is also important to ensure the food produced is safe and good. Thus, the first hypothesis for the study is:

$\mathrm{H} 1$ : There is a significant relationship between halal Food Processing and some elements of MFCA VA is a set of norms, something which was founded and established by authority as a rule for the measure of quantity, weight, extent, value, or quality. Accordingly, VA used standard cost for predetermined costs. Halal processing does not require a specifically comparative analysis like VA, but requires the food producers to have a set of standard materials and its composition to be used in their production. To maintain the quality, the food producers are required to constantly follow the standard set-up in their operation that has been used for halal certification. This, lead to second hypothesis, that is:

$\mathrm{H} 2$ : There is a significant relationship between halal Food Processing and some elements of VA

$\mathrm{KC}$ is the process of continual cost reduction that occurs after a product design has been completed and is now in production. The Japanese word 'kaizen' in kaizen costing may be somewhat different concept from the English word 'improvement' (Monden \& Hamada, 1991). The important feature of kaizen is continuous, which is used to signify the embedded nature of the practice and a never-ending journey towards quality and efficiency (Brunet \& New, 2003). In Islam, the followers are demanded to be istiqamah, which is described as consistency and passion for excellence (Kamaluddin \& Abdul Manan, 2010). Istiqamah requires the followers to excel in everything they do (Kamaluddin \& Abdul Manan, 2010). Islam requires the followers to do more than what is minimally required as Prophet Muhammad PBUH advised: "God loves that when anyone does a job, he does it perfectly", and, to be efficient and proficient as God mentions: "Verily Allah commands that you establish justice and be efficient and proficient." (Quran 16:90). Thus in halal processing, consistent is something demanded from the food producers, while continuous improvement is highly encouraged in their processing. Therefore, the third hypothesis is:

$\mathrm{H} 3$ : There is a significant relationship between halal Food Processing and some elements of KC $\mathrm{BM}$ is the process of measuring the performance of one's company against the best in the same or another industry. It used the knowledge and the experience of others to improve the organisation and analysing the performance (Lankford, 1996). This is done through discovering and incorporate the best practice by identified and understand the practice of a superior or world class performance in a particular work process (Demillio, 1995). Benchmarking is not a complex concept but it should 
INTERNATIONAL JOURNAL OF ACADEMIC RESEARCH IN BUSINESS AND SOCIAL SCIENCES

Vol. 8, No. 11, Nov, 2018, E-ISSN: 2222-6990 @ 2018 HRMARS

not be taken too lightly; it is basically learning from others. In fact, a benchmark with the upmost quality is highly encouraged in Islam as God says: "Indeed in the Messenger of Allah you have an excellent example (best practice) to follow for whoever hopes in Allah and the Last Day and remembers Allah much (best performance)." (Quran 33:21). Lastly, the fourth hypothesis is:

H4: There is a significant relationship between halal Food Processing and some elements of BM

\section{Methodology}

This study is a descriptive study, to examine the elements of MA techniques that are being practiced in halal food processing and to explore their relationships. This is the first ever study on the relationship between halal food processing with MA techniques. Currently, based on halal directory at Daganghalal website1, there are 3,597 registered sellers with 18,187 qualified compliance halal products in Malaysia. For the purpose of this study, the sample is randomly taken from the exhibitors at Malaysian International Halal Showcase (MIHAS) 2015. At MIHAS, there are 528 exhibitors from 21 countries that took part. Only Malaysian exhibitors are taken as samples for this study as they are the ones who need to comply with MS1500:2009.

Since MIHAS is a well-known venue for halal showcase throughout the world, it can be assumed that all the exhibitors involved in MIHAS are established halal food companies. These companies are ready to penetrate the international market. They have followed the requirement on halal processing stipulated in MS1500:2009 and Good Manufacturing Process2 (GMP). Therefore, they are the best respondents to answer about halal food processing and it relation with MA techniques.

The questionnaire is taken from Jalaludin, Sulaiman, \& Nik Ahmad (2010), Salina, Rohayati, Suzaida, Mohd Rizuan, \& Noraina Mazuin (2011) and Mohd Rizuan (2015). These questions are being amended to fit with MS1500:2009, Manual Procedure of Halal and Halal Assurance System (HAS), and also with certain elements of MFCA, VA, KC and BM. The likert scale is used in the questionnaire ranging from 1 as "strongly disagree" to 5 as "strongly agree". It is a self-administered questionnaire. The descriptive analysis is employed to analyse the MS1900:2005 compliance and its practicality. The descriptive statistics is important as it is required to understand further statistical evaluation which including the drawing of inferences (Spriestersbach, Röhrig, du Prel, Gerhold-Ay, Blettner, 2009). The Spearman rho correlation is conducted to assess the relationship between the halal processing and optimally use of resources.

\section{Results and Discussion}

During the data collection, more than 400 questionnaires were distributed. The returned and useable questionnaires were 303. The questionnaire distributed is not based on the company, but rather to the person in charge. Majority of the respondents (70.6\%) are employees of halal food's company, while others are either the owners or key management of the company. $50.8 \%$ of respondents said their company has obtained halal certification for 5 years and below, 20.1\% between $6-8$ years and $29 \%$ more than 8 years.

\footnotetext{
${ }^{1}$ Available at http://www.daganghalal.com/

2 Refers to set of regulations, codes and guidelines to control the operational conditions within a foods producing establishment allowing for the production of safe food
} 
INTERNATIONAL JOURNAL OF ACADEMIC RESEARCH IN BUSINESS AND SOCIAL SCIENCES Vol. 8, No. 11, Nov, 2018, E-ISSN: 2222-6990 (C) 2018 HRMARS

On the number of employees, $26.4 \%$ said they have 10 employees or less, $38.6 \%$ have between 11 to 50 employees and 35\% have more than 50 employees. Majority of the respondents $(60.1 \%)$ said their company employed 100\% Muslim, 33\% employed more than 50\% Muslim and $6.9 \%$ employed less than 50\% Muslim. Majority of the respondents (83.2\%) are from private company (Sdn Bhd), $12.5 \%$ from unincorporated business (Enterprise) and $4.3 \%$ from other types of business. $69 \%$ of the respondents have attended the halal course. The demographic profile of respondents is tabulated in Table 1.

Table 1: Demographic Profile of Respondents

\begin{tabular}{|c|c|c|c|c|c|}
\hline & $\begin{array}{c}\text { Frequenc } \\
\mathbf{y}\end{array}$ & Percent & & $\begin{array}{c}\text { Frequenc } \\
y\end{array}$ & Percent \\
\hline \multicolumn{3}{|c|}{ Position } & \multicolumn{3}{|c|}{ Classification of Business } \\
\hline $\begin{array}{l}\text { Owner / Key } \\
\text { Management }\end{array}$ & 89 & $29.4 \%$ & Sdn Bhd & 252 & $83.2 \%$ \\
\hline \multirow[t]{2}{*}{ Employee } & 214 & $70.6 \%$ & Enterprise & 38 & $12.5 \%$ \\
\hline & & & Other & 13 & $4.3 \%$ \\
\hline \multicolumn{3}{|c|}{ Years obtained Halal } & & & \\
\hline 5 years and below & 154 & $50.8 \%$ & \multicolumn{3}{|c|}{ Percentage of Muslim Employees } \\
\hline $6-8$ years & 61 & $20.1 \%$ & 100\% Muslim & 182 & $60.1 \%$ \\
\hline \multirow[t]{2}{*}{ More than 8 years } & 88 & $29.0 \%$ & $>50 \%$ Muslim & 100 & $33.0 \%$ \\
\hline & & & $<50 \%$ Muslim & 21 & $6.9 \%$ \\
\hline \multicolumn{3}{|c|}{ Number of Employees } & & & \\
\hline $\begin{array}{l}10 \text { employees and } \\
\text { below }\end{array}$ & 80 & $26.4 \%$ & \multicolumn{3}{|c|}{ Attend Halal Course } \\
\hline 11- 50 employees & 117 & $38.6 \%$ & Yes & 209 & $69.0 \%$ \\
\hline $\begin{array}{l}\text { More than } 50 \\
\text { employees }\end{array}$ & 106 & $35.0 \%$ & No & 94 & $31.0 \%$ \\
\hline
\end{tabular}

The reliability of the data was verified using Cronbach alpha, where the closer the Cronbach alpha to 1 , the higher the internal consistency or reliability (Sekaran, 2000). The alpha coefficients for all factors in this study are 0.90 and above, which can be concluded as being reliable (Nunnally, 1978). Table 2 presents the Cronbach alpha coefficient for each factor.

Table 2: Reliability Statistics

\begin{tabular}{|l|c|c|}
\hline & $\begin{array}{c}\text { Cronbach's } \\
\text { Alpha }\end{array}$ & N of Items \\
\hline Halal Clean and Safety (Toyyib) Processes & .900 & 16 \\
\hline Elements of material flows cost accounting & .952 & 10 \\
\hline Elements of variance analysis & .956 & 5 \\
\hline Elements of kaizen costing & .950 & 6 \\
\hline Elements of benchmarking & .924 & 4 \\
\hline
\end{tabular}


INTERNATIONAL JOURNAL OF ACADEMIC RESEARCH IN BUSINESS AND SOCIAL SCIENCES Vol. 8, No. 11, Nov, 2018, E-ISSN: 2222-6990 @ 2018 HRMARS

To answer the first research question on the requirement of MS1500:2009 on hygiene and safety of food, a descriptive analysis is conducted. The result is expected. Majority of respondents are strongly agreed that they have followed strictly the requirement of MS1500:2009. They have agreed that in processing the halal food, they always ensure that the processes flows are clean, equipment used is clean, smooth flow of materials to avoid contamination and known the material used in the processes. The result of MS1500:2009 requirement - hygiene and safety of food processing, is tabulated in Table 3 below:

Table 3: Descriptive Statistic on MS1500:2009 requirement - hygiene and safety of food processing

\begin{tabular}{|c|c|c|c|c|c|c|c|}
\hline $\begin{array}{l}\mathbf{N} \\
\mathbf{O}\end{array}$ & Items & Mean & SD & No & Items & $\begin{array}{r}\text { Mea } \\
n\end{array}$ & SD \\
\hline 1. & $\begin{array}{l}\text { Use clean processing } \\
\text { equipment }\end{array}$ & 4.4785 & $\begin{array}{c}.7668 \\
9\end{array}$ & 9. & $\begin{array}{l}\text { Sanitation } \\
\text { maintenance }\end{array}$ & $\begin{array}{r}4.488 \\
4\end{array}$ & .69936 \\
\hline 2. & $\begin{array}{l}\text { Processed products are } \\
\text { clean }\end{array}$ & 4.4587 & $\begin{array}{c}.6982 \\
3\end{array}$ & 10. & Avoid contamination & $\begin{array}{r}4.551 \\
2\end{array}$ & .69758 \\
\hline 3. & $\begin{array}{l}\text { Workflow of premise } \\
\text { layout }\end{array}$ & 4.5347 & $\begin{array}{c}.8084 \\
5\end{array}$ & 11. & $\begin{array}{l}\text { Use minimal food } \\
\text { additive }\end{array}$ & $\begin{array}{r}4.557 \\
8\end{array}$ & .73858 \\
\hline 4. & Supervision of hygiene & 4.5050 & $\begin{array}{c}.7842 \\
5 \\
\end{array}$ & 12. & $\begin{array}{l}\text { No pest species in } \\
\text { premise }\end{array}$ & $\begin{array}{r}4.514 \\
9 \\
\end{array}$ & .70402 \\
\hline 5. & Cleanness of the premise & 4.5644 & $\begin{array}{c}.6869 \\
0\end{array}$ & 13. & $\begin{array}{l}\text { Premise is free from } \\
\text { animals }\end{array}$ & $\begin{array}{r}4.534 \\
7\end{array}$ & .78349 \\
\hline 6. & Premise maintenance & 4.5743 & $\begin{array}{c}.6563 \\
0\end{array}$ & 14. & $\begin{array}{l}\text { Traceability of } \\
\text { resources }\end{array}$ & $\begin{array}{r}4.508 \\
3\end{array}$ & .74079 \\
\hline 7. & Free from contamination & 4.4389 & $\begin{array}{c}.8027 \\
7\end{array}$ & 15. & $\begin{array}{l}\text { Traceability in process } \\
\text { flows }\end{array}$ & $\begin{array}{r}4.528 \\
1 \\
\end{array}$ & .68453 \\
\hline 8. & $\begin{array}{l}\text { Sufficiency of sanitation } \\
\text { facilities }\end{array}$ & 4.4191 & $\begin{array}{c}.7629 \\
0\end{array}$ & 16. & $\begin{array}{l}\text { Structured system for } \\
\text { waste disposal }\end{array}$ & $\begin{array}{r}4.468 \\
6\end{array}$ & .74017 \\
\hline
\end{tabular}

For the second research question, the MA techniques that inherently practice by food producers in halal food processing. Again, a descriptive analysis is conducted. The result is very encouraging. This study revealed that the halal food processing in Malaysia had inherently practices some of the MA techniques in their food processing. The respondents agreed that the resources are used effectively. The respondents claimed that they fully understand about the material process flow and the output from the process. In order to maintain a good processing, the respondents agreed that their organisation has proper process flow chart. They also agreed, with a proper system they have, benchmarking can be done. Thus, majority of respondents have claimed that their organisation has benchmarked their products and processes with other halal products.

Since halal processing consider traceability of resources as critical point to be observed, a proper record is required and need to be maintained. Through a proper record, any differences with actual practices can be identified. Thus, majority of the respondents agreed their organisation has identified the input cost, planned and controlled the cost. Moreover, they also look for differences on any variances occurred. Lastly, in ensuring a good processing is maintained, the organisation is required to be consistent (istiqamah). From the survey, the respondents have agreed that their organisation 
INTERNATIONAL JOURNAL OF ACADEMIC RESEARCH IN BUSINESS AND SOCIAL SCIENCES Vol. 8, No. 11, Nov, 2018, E-ISSN: 2222-6990 @ 2018 HRMARS

always ensures the productions are at equivalent quality and make periodic reviews to improve the processes and products. The detailed descriptive statistic of elements of MA techniques used in halal food processing is tabulated in Table 4 below.

Table 4: Elements of MA Techniques Practices in Halal Food Processing

\begin{tabular}{|c|c|c|c|c|c|c|c|}
\hline No. & Items & Mean & SD & No. & Items & Mean & SD \\
\hline \multicolumn{4}{|c|}{$\begin{array}{l}\text { Elements of Material Flow Cost Accounting } \\
\text { (MFCA) }\end{array}$} & \multicolumn{4}{|c|}{ Elements of Variance Analysis (VA) } \\
\hline 1. & Effective use of water & 4.3399 & .78897 & 1. & $\begin{array}{l}\text { Identified the input } \\
\text { costs }\end{array}$ & 4.4686 & .69875 \\
\hline 2. & Effective use of energy & 4.4191 & .72278 & 2. & $\begin{array}{l}\text { Planned for } \\
\text { production costs }\end{array}$ & 4.4455 & .80736 \\
\hline 3. & Effective use of labour & 4.5248 & .62393 & 3. & Controlled the costs & 4.3993 & .83523 \\
\hline 4. & Managing waste & 4.4323 & .71029 & 4. & Compare the cost & 4.3894 & .77213 \\
\hline 5. & $\begin{array}{l}\text { Traceability of raw } \\
\text { materials }\end{array}$ & 4.4983 & .70417 & 5. & $\begin{array}{l}\text { Identified } \\
\text { differences }\end{array}$ & 4.4224 & .70927 \\
\hline 6. & $\begin{array}{l}\text { Identify the task of } \\
\text { workforce }\end{array}$ & 4.4686 & .73117 & & & & \\
\hline 7. & $\begin{array}{l}\text { Identify the quantity to } \\
\text { produce }\end{array}$ & 4.4422 & .72500 & \multicolumn{4}{|c|}{ Elements of Kaizen Costing (KC) } \\
\hline 8. & $\begin{array}{l}\text { Identify the quality to } \\
\text { produce }\end{array}$ & 4.4785 & .69913 & 1. & $\begin{array}{l}\text { Consistency in } \\
\text { production }\end{array}$ & 4.3399 & .75025 \\
\hline 9. & $\begin{array}{l}\text { Ensuring targeted } \\
\text { quantity }\end{array}$ & 4.4752 & .67492 & 2. & \begin{tabular}{|l|}
$\begin{array}{l}\text { Periodic product } \\
\text { reviewed }\end{array}$ \\
\end{tabular} & 4.4389 & .79030 \\
\hline 10. & $\begin{array}{l}\text { Ensuring targeted } \\
\text { quality }\end{array}$ & 4.4389 & .62142 & 3. & \begin{tabular}{|l|l|}
$\begin{array}{l}\text { Periodic process } \\
\text { reviewed }\end{array}$ \\
\end{tabular} & 4.4818 & .74061 \\
\hline \multicolumn{4}{|c|}{ Elements of Benchmarking (BM) } & 4. & $\begin{array}{ll}\text { Ensuring } & \text { right } \\
\text { processing }\end{array}$ & 4.4983 & .68510 \\
\hline 1. & BM with other products & 4.4092 & .76178 & 5. & $\begin{array}{l}\text { Identify product } \\
\text { advantages }\end{array}$ & 4.4686 & .71283 \\
\hline 2. & Creating marker levels & 4.4884 & .71342 & 6. & $\begin{array}{l}\text { Identify product } \\
\text { weaknesses }\end{array}$ & 4.4059 & .72118 \\
\hline 3. & BM for processing & 4.4686 & .71283 & & & & \\
\hline 4. & Process flow chart & 4.4983 & .68510 & & & & \\
\hline
\end{tabular}

On the third research question, the significant relationship between MS1500:2009 requirement on hygiene and safety of food and MA techniques in halal food processing. A Spearman's rho correlation is conducted. The analysis shows that there are significant relationships between the independent variables with all the dependents variables. Therefore, all the hypotheses are accepted as there are strong positive relationship between MS1500:2009 requirement on hygiene and safety in halal food industries and the elements of MA techniques, which are (a) MFCA, (b) VA, (c) KC and (d) BM. The result of Spearman's rho correlation is shown as in Table 6. 
INTERNATIONAL JOURNAL OF ACADEMIC RESEARCH IN BUSINESS AND SOCIAL SCIENCES

Vol. 8, No. 11, Nov, 2018, E-ISSN: 2222-6990 @ 2018 HRMARS

Table 6: Spearman's rho Correlations

\begin{tabular}{|l|c|c|c|c|c|}
\hline & $\begin{array}{c}\text { Halal Clean } \\
\text { and Safety }\end{array}$ & MFCA & VA & KC & BM \\
\hline Correlation & 1.000 & $.918^{* *}$ & $.899^{* *}$ & $.839^{* *}$ & $.821^{*}$ \\
Coefficient &. & .000 & .000 & .000 & .000 \\
Sig. (2-tailed) & 303 & 303 & 303 & 303 & 303 \\
$\mathrm{~N}$ & & &
\end{tabular}

**. Correlation is significant at the 0.01 level (2-tailed).

\section{Conclusions}

The finding of this study is very refreshing. This study revealed that the halal food producers have inherently practices some of the MA techniques in their food processing. In ensuring the halal food processes follow the MS1500:2009 requirement, the industry has embedded indirectly some of the MA techniques that have proven benefited the businesses, such as MFCA, VA, KC and BM.

The most important finding reveals in this study is that the halal food processing is beyond the Muslims food issue. The basic concepts of food in Islam, which is halal and toyyib, is a universal concept that shall be applied to all. These concepts emphases on the safe food through a good processing system, starting from the source of the materials until it becomes a consumable food. Thus, halal is more than Muslim food. Halal is a good food produced through a good system, encompasses of material identifiable and traceable, hygienic processing, safe food and good processing system.

Therefore, it is suggested that a thorough study on halal food processing to be done. The contribution of halal food processing to its producer's cost management system needs to be investigated in detail. This shall be done through a case study by detailing the processes and cost management system implemented during the processes. By doing that, the halal food processing standard can be further enhance by introducing the cost management system within its standard. The emphasis on the hygienic processing with a good manufacturing system is a universal issue that shall apply to all food industries. The belief about halal is a food for Muslims must be changed as halal indicates a good, hygienic and safe food for human consumption. 
INTERNATIONAL JOURNAL OF ACADEMIC RESEARCH IN BUSINESS AND SOCIAL SCIENCES

Vol. 8, No. 11, Nov, 2018, E-ISSN: 2222-6990 @ 2018 HRMARS

\section{References}

Al-Qaradawi, Y. (2001). The Lawful and Prohibited in Islam. Retrieved April 28, 2015, from http://www.dartmouth.edu/ dcare/pdfs/yusuf.pdf

Anastas, M. (1997, October). The changing world of management accounting and financial management. Management Accounting, 48-51.

Beer, E. (2014). Global Halal Market To Hit \$1.6tn by 2018. Foodnavigator.com. Retrieved December 24, 2014, from http://www.foodnavigator.com/Regions/Middle-East/Global-Halal-market-tohit-1.6tn-by-2018?utm_source=copyright\&utm_medium=OnSite\&utm_campaign=copyright

Bohari, A. M., Hin, C. W., \& Fuad, N. (2013). The competitiveness of halal food industry in Malaysia : A SWOT - ICT analysis. Malaysia Journal of Society and Space, 1(1), 1-9.

Brunet, A. P., \& New, S. (2003). Kaizen in Japan: An Empirical Study. International Journal of Operations \& Production Management, 23(12), 1426-1446.

Chompu-inwai, R., Jaimjit, B., \& Premsuriyanunt, P. (2014). A combination of Material Flow Cost Accounting and design of experiments techniques in an SME : the case of a wood products manufacturing company in northern Thailand. Journal of Cleaner Production, 1-13. doi:10.1016/j.jclepro.2014.08.039

Cwiertka, K. \& Walvaren, B. (2002). Asian Food: The Local and the Global, Curzon Press: Survey.

Dasgupta, S. (2011). China makes dent in halal market with 1/8th of India's Muslim population http://articles.timesofindia.indiatimes.com/2011-09-21/china/30183710_1_halal-chinacountries (accessed 23 Jan 2013). The Times of India. Retrieved July 30, 2015, from http://articles.timesofindia.indiatimes.com/2011-09-21/china/30183710_1_halal-chinacountries

Demillio, R. (1995). The Basics of Benchmarking (1st ed.). Portland: Productivity Press.

Habibah, H., Talib, A., Anuar, K., Ali, M., \& Jamaludin, K. R. (2008). Quality Assurance in Halal Food Manufacturing in Malaysia : A Preliminary Study. In International Conference on Mechanical \& Manufacturing Engineering (ICME2008) (pp. 21-23).

IslamOnline.net. (2006). Malaysian halal food industry : A role model. Retrieved from http://www.IslamOnline.net

Jalaludin, D., Sulaiman, M., \& Nik Ahmad, N. N. (2010). Environmental Management Accounting: An Empirical Investigation of Manufacturing Companies in Malaysia. Asia Pasific Centre for Environmental Accountability, 16(3).

Jayeola, O., Sokefun, A. O., \& Oginni, B. O. (2012). Kaizen Cost Management Technique and Profitability of Small and Medium Scale Enterprises (SMEs) in Ogun State, Nigeria. Pakistan Journal of Social Sciences, 9(3), 147-154. doi:10.3923/pjssci.2012.147.154

Kamaluddin, N., \& Abdul Manan, S. K. (2010). The conceptual framework of Islamic Work Ethic (IWE). Malaysian Accounting Review, 9(2), 57-70.

Kokubu, K., \& Kitada, H. (2014). Material flow cost accounting and existing management perspectives. Journal of Cleaner Production, 1-10. doi:10.1016/j.jclepro.2014.08.037

Kokubu, K., Kos, M., \& Campos, S. (2009). Material Flow Cost Accounting with ISO 14051, (February), 15-18.

Lankford, W. M. (1996). Benchmarking: Understanding the basics, 1(1), 57-62. 
INTERNATIONAL JOURNAL OF ACADEMIC RESEARCH IN BUSINESS AND SOCIAL SCIENCES

Vol. 8, No. 11, Nov, 2018, E-ISSN: 2222-6990 @ 2018 HRMARS

Michael Anastas, "The Changing World of Management Accounting and Financial Management," Management Accounting, October 1997.

Mohamad, N., \& Backhouse, C. (2014). A Framework for the Development of Halal Food Products in. In International Conference on Industrial Engineering and Operations Management (pp. 693702).

Mohd Rizuan, A. K. (2015). Environment Management Accounting (Ema) Practices in Halal Food Processing Ms1500:2009. South East Asia Journal of Contemporary Business, Economics and Law, 7(1), 32-39.

Mohd Rizuan, A. K., Zaifudin, Z., Salina, D., \& Noraina Mazuin, S. (2015). Incorporating the Cost Management System in Halal Standard MS 1500 : 2009 Halal Food in Malaysia By : International Research Journal of Education and Innovation (IRJEI), 1(4), 1-13.

Mohd Yusoff, H. (2004). Halal certification scheme. Standard \& Quality News 11.1, 4-5.

Monden, Y., \& Hamada, K. (1991). Target costing and kaizen costing in japanese automobile companies. Journal of Management Accounting Research, 3, 16-34.

Noordin, N., Md Noor, N. L., Hashim, M., \& Samicho, Z. (2009). Value Chain of Halal Certification System: A Case of the Malaysia Halal Industry. In European and Mediterranean Conference on Information Systems 2009 (EMCIS2009) (pp. 1-14).

Nunnally, J. C. (1978). Psychometric Theory (2nd ed.). Boston: McGraw Hill.

Poretsky, S. (2012). What Does Kaizen Mean When Applied to Its Use in a Business? Demand Media.

Saadan, M., \& Zainal Abidin, Y. (2014). Halalkah Makanan Kita? (1st ed.). Batu Caves, Selangor: PTS Islamika.

Saifuddeen, M. (2006). Food and technological progress: an Islamic perspective (p. 193). MPH Group Pub. in cooperation with the Institute of Islamic Understanding Malaysia (IKIM), Kuala Lumpur.

Salina, D., Rohayati, C. D., Suzaida, B., Mohd Rizuan, A. K., \& Noraina Mazuin, S. (2011). Implementation of MS1500: 2009: A Gap Analysis. Communications of the IBIMA, 2011, 1-11. doi:10.5171/2011.360500

Samori, Z., Ishak, H. \& Kassan, N. H. (2014). Understanding the development of halal food standard: suggestion for future research. International Journal of Social Science and Humanity 4.6, 482.

Sekaran, U. (2000). A Skill-building Approach. Research Methods for Business.

UNDSD. (2001). Environmental Management Accounting : Policies and Linkages. 